\title{
Sustainable Development of Single-Industry Towns in Siberia and the Russian Far East: What is the Price of Regional Economic Growth?
}

\author{
Yulia II. Pyzheva* \\ Siberian Federal University \\ Krasnoyarsk, Russian Federation
}

Received 21.11.2019, received in revised form 31.03.2020, accepted 10.04.2020

\begin{abstract}
One of the most well-known and relatively easy to compute integral indicators of sustainable development is the indicator of genuine savings. In the present article the emphasis is made on the modifications of the method of genuine savings calculation for the level of municipal units on the example of single-industry towns (monotowns) of Siberia and the Russian Far East. This choice of the object of the study is conditioned by the hypothesis that it is municipalities that experience most of the environmental and social consequences of economic growth in regions. The enterprises' reports gave rise to the database, which was then used to calculate the genuine savings values of Siberian and Far Eastern single-industry towns. The result is a new classification of single-industry towns, which includes four clusters allocated depending on the level of genuine savings, industry of specialization and population. The new approach to the classification of singleindustry towns can be used by regional and municipal authorities to form a differentiated policy for the sustainable development. The analysis of the average genuine savings of different towns by region has shown that even if the region as a whole is characterized by quite high values of genuine savings, the towns, in which there are real enterprises that yield most of the gross domestic product of the country, experience negative values of genuine savings and are often on the verge of environmental or social disaster.
\end{abstract}

Keywords: sustainable development, genuine savings, indicators of sustainable development, single-industry towns, environmental and resource economics.

The reported study was funded by Russian Foundation for Basic Research according to the research project No. 19-010-00841.

Research area: economics and national economy.

Citation: Pyzheva, Yu.I. (2020). Sustainable development of single-industry towns in Siberia and the Russian Far East: what is the price of regional economic growth? J. Sib. Fed. Univ. Humanit. Soc. Sci., 13(4), 582-590. DOI: 10.17516/1997-1370-0591.

\footnotetext{
(C) Siberian Federal University. All rights reserved

* Corresponding author E-mail address: ystartseva@sfu-kras.ru ORCID: 0000-0003-0973-5073
} 


\section{Introduction}

Currently, the world's leading countries are concerned about the transition to development trajectories that not only maximize economic growth, but also pay considerable attention to compensation for environmental degradation. At the same time, there is an urgent need for the search for adequate ways to jointly assess the dynamics of economic growth and its environmental consequences, and also the need for the study of the sustainability of the development of economic systems at various levels, including regions and municipalities.

In the decades since Brundtland's report (1987), dozens of tools for assessing sustainability have been developed and applied by various research teams and international organizations worldwide (Barrington-Leigh, Escande, 2018; Cobb et al., 1995; Costanza et al., 2014; Daly, Cobb, 1989).

One of the most common tools used to assess sustainability is the integral indicator, Genuine Savings (Pearce, Atkinson, 1993; Bolt et al., 2002). Sufficiently wide experience has been accumulated in assessing the sustainability of both Russia as a whole and its individual regions with the application of various tools (Bobylev, 2011; Belik, Pryakhin, 2013; Glazyrina et al., 2010; Zabelina, Klevakina, 2011; Ryumina, 2013). In particular, there are quite a few works to assess the genuine savings of individual regions or other sub-federal entities in Russia (Bobylev et al., 2011, 2012; Mekush, 2011; Korobitsyn, 2015). The purpose of our long-term work was to propose a modification of the method of genuine savings estimation for the level of Russian regions and municipal entities, which would enable increasing the accuracy of estimates and make them comparable in time. The method developed for calculating genuine savings for the regions is going to be introduced into the Russian statistical accounting system and can be used by both state and executive authorities. Proposals on introduction of the methodology of calculation of genuine savings of regions into the system of Russian statistics are enlisted in the recently published work (Pyzhev et al., 2019). This article focuses on modifications of the author's methodology developed for the level of municipalities on the example of single-industry towns of Siberia and the Far East. From our point of view, it is critically important to consider the economic systems of regions through the prism of municipal units which generate the bulk of gross value added and, as a consequence, it is the cities and towns that are experiencing most of the environmental impact. This is especially obvious for towns which manufacture mostly one type of products critical for the region, and it is the environmental and social policy of one particular enterprise that determines the quality of life of the population both in the single-industry towns and in the region as a whole.

\section{Methodology}

The value of genuine savings (GS) in the region, according to our methodology, characterizes the rate of savings' accumulation after proper accounting of the depletion of natural resources and damage from environmental pollution. The indicator is the result of correction of gross domestic savings. There are three main stages of correction: at the first stage, the amount of fixed capital depreciation is subtracted from gross domestic savings (in Russian statistics, depreciation of fixed assets can be regarded as an analogue of this indicator). At the second stage, genuine savings are increased by the amount of education expenses enhancing the human capital. From the point of view of sustainable development, the third stage is fundamentally important, as here the depletion of natural capital (energy and mineral resources, as well as the balance of changes in forest resources) and damage from environmental pollution (emissions of $\mathrm{CO}_{2}$ and particulate matter) are subtracted. All values included in the calculation are taken as a percentage of gross national income.

Thus, the value of genuine savings of regions is determined as follows:

$$
\begin{aligned}
& \mathrm{GS}=(\mathrm{TS}-\mathrm{FPC}+\mathrm{HC}- \\
& -\mathrm{DNR}-\mathrm{ED}) / \mathrm{GRDP} \times 100 \%,
\end{aligned}
$$

where TS are gross savings ( $\mathrm{mln}$ rub.); rub.);

FPC is fixed capital consumption (mln HSC is investment in human capital ( $\mathrm{mln}$ rub.); 
Yulia I. Pyzheva. Sustainable Development of Single-Industry Towns in Siberia and the Russian Far East...

Table 1. Features of author's GS calculation methodology

\begin{tabular}{|l|l|}
\hline \multicolumn{1}{|c|}{ GS component } & \multicolumn{1}{c|}{ Indicators used for evaluation } \\
\hline Gross Savings & Gross fixed capital formation \\
\hline $\begin{array}{l}\text { Consumption } \\
\text { of fixed capital }\end{array}$ & $\begin{array}{l}\text { Accrued for the accounting year depreciation of fixed assets (depreciation and } \\
\text { amortization recorded in the accounting and reporting periods) of commercial and } \\
\text { non-commercial organizations by all forms of ownership }\end{array}$ \\
\hline $\begin{array}{l}\text { Investments in } \\
\text { human capital }\end{array}$ & $\begin{array}{l}\text { - Expenditures of consolidated budgets of RF subjects concerning education and } \\
\text { healthcare; } \\
\text { - Grants to leading universities; } \\
\text { - Consumer spending of households on education and health }\end{array}$ \\
\hline $\begin{array}{l}\text { Damage from } \\
\text { environmental pollution }\end{array}$ & $\begin{array}{l}\text { 1) Valuation of damage from emissions of pollutants from stationary sources: } \\
- \text { carbon dioxide, } \\
\text { - hydrocarbons without VOC (methane), } \\
\text {-nitrous oxides. } \\
\text { 2) Cost estimates of carbon dioxide emissions from mobile sources (based on CO } \\
\text { emissions, average fuel consumption, vehicle mileage and number of vehicles } \\
\text { registered in the territory) }\end{array}$ \\
\hline $\begin{array}{l}\text { Depletion of mineral } \\
\text { and energy resources }\end{array}$ & $\begin{array}{l}\text { Valuation of the depletion of natural resources: } \\
\text { - oil, natural gas, coal; } \\
\text { - gold, copper, nickel }\end{array}$ \\
\hline $\begin{array}{l}\text { Depletion of forest } \\
\text { resources }\end{array}$ & $\begin{array}{l}\text { Valuation of forest resource depletion coupled with reforestation costs (based on } \\
\text { forest auction data) }\end{array}$ \\
\hline
\end{tabular}

DNR is the cost of depletion of non-renewable natural resources ( $\mathrm{mln}$ rub.);

ED is the damage from environmental pollution (mln rub.);

GRDP is the gross regional domestic product (mln rub.).

Features of evaluation of each component are given in Table 1.

\section{Genuine Savings of Siberia and the Russian Far East regions}

Previously, the researchers estimated genuine savings of the regions of Siberia and the Far East in 2000s and 2010s using the above-described methodology (Syrtsova et al., 2016; Pyzheva et al., 2020). For example, estimates of genuine savings of Siberian regions are presented in Table 2.

The analysis of the received estimates demonstrates a certain regularity: in 2015 negative values of genuine savings are characteristic for resource-mining regions and regions where large scale harmful processing industries are located. Such regions are primarily the Kemerovo Oblast (-14\%), Tomsk Oblast (-6.4\%), Irkutsk Oblast (-3.3\%), Krasnoyarsk Krai
$(-0.9 \%)$. The Kemerovo Oblast has the largest number of single-industry towns (monotowns) among the regions of Siberia and the Far East, which were created in connection with coal mines. The Tomsk Oblast traditionally specializes in the extraction of iron ores, peat and oil, but only the city of Kemerovo has received the single-industry town status. Seversk, which is home to the Siberian Chemical Combine JSC, which belongs to the nuclear industry. In the Irkutsk Oblast (-3.3\%) gold, coal and iron ore mining accounts for a large share of mining operations, while machine-building, metallurgy and logging account for a large share of manufacturing operations. The Krasnoyarsk Krai has a minimal negative value approaching 0 $(-0.9 \%)$, despite huge reserves of various minerals: nickel ores (95\% of Russian reserves), gold (about $20 \%$ of Russian reserves), coal and lead ores. It is obvious that such a low negative value of GS in large-scale resource extraction is explained by substantial investments in modernization of production facilities, which not only improve their production efficiency, but also have a positive impact on environmental safety (expressed as a reduction of emissions 
Table 2. Estimates of GS of Siberian regions in 2004-2015, \% GRDP

\begin{tabular}{|l|c|c|c|c|c|}
\hline \multicolumn{1}{|c|}{ Region } & 2004 & 2007 & 2010 & 2014 & 2015 \\
\hline Altai Republic & 39.3 & 56.0 & 59.2 & 47.9 & 33.1 \\
\hline Republic of Buryatia & 10.6 & 19.4 & 25.3 & 17.6 & 13.3 \\
\hline Republic of Tuva & 27.5 & 32.4 & 37.6 & 51.8 & 34.9 \\
\hline Republic of Khakassia & 10.2 & 15.9 & 12.1 & 15.1 & 5.9 \\
\hline Altai Krai & 17.4 & 23.9 & 22.2 & 28.6 & 20.3 \\
\hline Zabaikalsky Krai & 21.4 & 20.3 & 19.9 & 19.9 & 20.5 \\
\hline Krasnoyarsk Krai & 5.8 & 12.9 & 11.6 & 1.4 & -0.9 \\
\hline Irkutsk Oblast & 8.5 & 29.6 & 10.7 & 3.9 & -3.3 \\
\hline Kemerovo Oblast & -1.5 & -2.1 & 1.6 & -2.4 & -14.0 \\
\hline Novosibirsk Oblast & 16.3 & 24.8 & 25.0 & 24.7 & 18.8 \\
\hline Omsk Oblast & 13.9 & 25.1 & 20.1 & 17.6 & 15.1 \\
\hline Tomsk Oblast & -15.6 & 9.2 & 2.0 & -3.6 & -6.4 \\
\hline
\end{tabular}

Source: (Syrtsova et al., 2016).

Table 3. Estimates of GS of Far East regions, \% GRP

\begin{tabular}{|l|c|c|c|c|c|}
\hline \multicolumn{1}{|c|}{ Region } & 2004 & 2007 & 2010 & 2014 & 2015 \\
\hline Sakha Republic (Yakutia) & -0.8 & 34.7 & 10.7 & -0.9 & -15.8 \\
\hline Kamchatka Oblast & 2.3 & 3.3 & 14.3 & -35.1 & 15.0 \\
\hline Primorsky Krai & 7.9 & 19.5 & 41.2 & 16.2 & 11.9 \\
\hline Khabarovsk Krai & 25.3 & 36.0 & 44.2 & 19.4 & 7.7 \\
\hline Amur Oblast & 36.6 & 47.9 & 45.2 & 24.0 & 14.3 \\
\hline Magadan Oblast & -1.5 & 29.5 & 19.1 & 12.4 & 17.6 \\
\hline Sakhalin Oblast & 83.4 & 22.1 & 0.5 & -5.9 & -14.6 \\
\hline Jewish Autonomous Oblast & 31.5 & 49.1 & 60.7 & 17.6 & 18.2 \\
\hline Chukotka Autonomous Okrug & 87.4 & 30.9 & -36.2 & -44.0 & -56.3 \\
\hline
\end{tabular}

Source: (Pyzheva et al., 2020).

into the atmosphere and, consequently, an increase in GS value).

Similar conclusions can be drawn from estimates of GS savings of the Far East regions on a corresponding time horizon (Table 3).

Analysis of GS of the Far East regions also points to three leading raw material regions (according to data for 2015): The Republic of Sakha (Yakutia) (-15.8), Sakhalin Oblast (-14.6), Chukotka Autonomous District (-56.3). In all the above-mentioned regions the structure of gross value added is dominated by minerals extraction and there is a sharp upsurge in natural resources depletion due to the boost of hydrocarbon production in the regions. The Magadan Oblast is an exception, since despite the predominant role of extraction of minerals, GS there are much higher than zero. The reason for this is the dynamics of gross savings of regions: the majority of regions have negative dynamics for the period under consideration, while for the Magadan Oblast it is positive. Over the studied period (2004-2015) the Magadan Oblast's GS value displayed negative dynamics. The GRDP of the Magadan Oblast grew in 4.7 times, while the gross savings of 
Magadan Oblast grew in 12.5 times. Thus, the annual increase in the share of gross savings (\% of GRDP) allows the region to keep positive GS while natural resources are being depleted due to the increase in gold production, with stable coal production volumes. As for positive GS, the maximum value can be observed in the Jewish Autonomous Oblast. The given territory does not possess mineral and raw material base for development of mining sector, hence, the value of exhaustion of natural resources is minimal, so the value of GS is high.

\section{Genuine Savings of Single-Industry Towns of Siberia and the Far East}

Let us consider what role single-industry towns play in ensuring genuine regional savings (Tables 2 and 3) and what consequences are experienced by the population living there. At present, 89 out of 312 single-industry towns of the Russian Federation are located in Siberia and the Far East. A more detailed analysis of the economy of these single-industry towns on the basis of their development indicators, which were determined by Order of the Russian Government No. 170-r dated February 2 , 2017, shows that the existing grouping of three categories, depending on the risks of socio-economic deterioration, does not take into account the existing significant features of towns and does not provide for adequate management solutions to improve the quality of life of the population. In our opinion, the policy implications should take into account at least the sectoral affiliation and the scale of settlements, since it is impossible to apply the same measures to towns in which value added is formed according to completely different principles.

According to the results of the audit of available statistical information, we have formed a database on single-industry towns in Siberia and the Far East, which includes such data as the industry affiliation of the towns, the names of the town-forming enterprises, the number of town population, the number of people working at the town-forming enterprises, the unemployment rate, the revenue of the town-forming enterprise, the cost price of sold products of the town-forming enterprise, investments in the fixed assets of the town.
When compiling the database, the following data were used: data from Rosstat; data provided by municipal statistics bodies; data contained in the State reports on the state of the environment of the Russian Federation and regions; annual reports of town-forming enterprises; data from the accounting reports of town-forming enterprises, obtained from the database Kontur.Focus. Static estimates of GS for monotowns in Siberia and the Far East for 2018 were obtained using the database created. The purpose of calculating GS for single-industry towns was to form an alternative classification, taking into account sectoral specificity of towns, which is necessary to improve the quality of life there. Currently, many economically successful industrial towns face the problem of critical deterioration of the environmental situation, which may lead to their unsuitability for the population, while other municipalities, whose businesses are on the verge of closure, face a sharp outflow of population due to lack of jobs and for this reason they are on the verge of extinction. In order to make calculations at the level of towns, the author's methodology for calculating GS for regions was modified (see (1)). As a proxy variable for gross savings of cities, Net investment in fixed assets of the town-forming enterprise (got from open accounting forms) was used. Pollution damage was evaluated on the basis of a minimum estimate (due to a dramatic lack of statistical observations for pollutant emissions), namely, the gross emissions of town-forming enterprises, which were equated to the cost estimate of $\mathrm{CO}_{2}$ emissions, since not all enterprises provide information on emissions in terms of pollutants. Depletion of mineral resources was estimated by the cost of extraction for the subsoil user company (including costs not directly related to extraction).

Based on the results of the calculation of GS of Siberian and Far Eastern cities, as well as taking into account the sector and scale of settlements, there were identified four clusters of monotowns:

1) towns with a positive value of GS (therefore, they are characterized by relative sustainability of development) and town-forming en- 
terprises presumably do not have a significant impact on the city environment (mainly this group includes towns specializing in food and beverage production, road/bridge construction, rail transport services as the basic employment facilities);

2) towns, which have values of GS close to zero and town-forming enterprises that significantly degrade the ecology of the city, while not producing natural resources in the immediate vicinity of the city (mainly this group includes towns that concentrate on metallurgical, engineering, woodworking, chemical production and distribution of electricity);

3) towns with negative values of GS and town-forming enterprises devoted to mining natural resources (coal, iron ores, ores of rare earth metals, diamonds);

4) towns, for which there is no statistical information, in view of the fact that their enterprises are either liquidated, or are in the process of liquidation.

Table 4 presents the average estimates of GS of Siberian and the Far Eastern single-in- dustry towns by regions, indicating their prevailing cluster.

It is easy to notice that even in the regions with positive total GS, the average GS of all monotowns have a negative value. This only confirms the hypothesis expressed at the beginning of the article that these towns experience the major consequences of intensive industrial development. For example, the maximum negative value of the average GS for the Krasnoyarsk Krai is explained by the presence of Norilsk, a big single-industry town with the most powerful mining and metallurgical production, the Polar Division of Norilsk Nickel Company. It should be noted that the total value of GS in the Krasnoyarsk Krai is not the lowest, which is explained by large-scale investments in modernization of production facilities, including environmental investments. However, within a particular town, it can be seen that environmental damage in the form of air emissions exceeds investment in fixed assets. It is also interesting to note that the $\mathrm{Ke}$ merovo Oblast, which has the highest negative

Table 4. GS Estimates of single-industry towns of Siberia and the Far East in 2018, \% GRDP

\begin{tabular}{|c|c|c|}
\hline Region & Prevailing cluster & $\begin{array}{c}\text { GS (weighted } \\
\text { by population of towns), \% GRDP }\end{array}$ \\
\hline \multicolumn{3}{|c|}{ Siberia } \\
\hline Altai Krai & 2 & 0.05 \\
\hline Republic of Buryatia & $\mathrm{e} 2$ & -0.72 \\
\hline Republic of Khakassia & $2-3$ & -0.32 \\
\hline Zabaikalsky Krai & 3 & -0.93 \\
\hline Krasnoyarsk Krai & 2 & -2.17 \\
\hline Irkutsk Oblast & $2-3$ & -0.42 \\
\hline Kemerovo Oblast & 3 & -0.19 \\
\hline Novosibirsk Oblast & 2 & 0.05 \\
\hline Omsk Oblast & 1 & 0.03 \\
\hline Tomsk Oblast & 2 & -1.16 \\
\hline \multicolumn{3}{|c|}{ Far East } \\
\hline Sakha Republic (Yakutia) & 3 & -0.55 \\
\hline Primorsky Krai & $2-3$ & -0.003 \\
\hline Khabarovsk Krai & $2-3$ & -0.28 \\
\hline Amur Oblast & 1 & -0.21 \\
\hline Chukotka Autonomous Okrug & $3-4$ & -0.94 \\
\hline
\end{tabular}

Source: author's calculations. 
value of total GS in the region among Siberian regions, is not characterized by the highest negative value of average GS calculated for every single-industry town. In our opinion, such a situation may be connected with the fact that those industries that determine negative GS are located in larger cities that do not have the status of a single-industry town. In any case, the majority of single-industry towns in the Kemerovo Oblast are towns created to work with coal mines and open-pit mines, undergoing all the negative environmental impacts of the coal industry, and once the operation life of mines and open-pit mines has come to an end, the towns will move to cluster no. 4 and turn out to be on the verge of closure. For the Altai Krai, the Novosibirsk Oblast and the Omsk Oblast as a whole, as well as single-industry towns on average, positive GS estimates have been received. The only towns in the Omsk Oblast and Krasnoyarsk Krai, which exert no significant negative impact on the environment, specialise in the food industry. As for the Altai Krai and the Novosibirsk Oblast, where the chemical industry, machine-building and construction materials industries are predominantly developed, we should note that the listed industries have an unquestionably negative impact on the environment, but the scale of this impact, compared with, for example, the metallurgical industry, is undoubtedly several times smaller. Besides, at relatively small scale of production it is much easier to "reimburse" the environmental damage by investments in the fixed capital of the enterprise.

The resource producing regions, such as Chukotka Autonomous Okrug (-0.94\%), the Republic of Sakha (Yakutia) (-0.55\%) and the Khabarovsk Krai (-0.28\%), are singled out by the calculated average GS value of the single-industry towns of the Far East as well as by the total GS of the regions. It is interesting that for the Khabarovsk Krai total GS value of the region is positive and amounts to $7.7 \%$ of GRDP, which correlates well with the fact that there are only two single-industry towns on the territory of the region: with the preponderant coal industry and with the prevalent machine building industry. Obviously, it is the coal industry that predetermines the negative GS average value in the Khabarovsk Krai monotowns. It is worth mentioning that half of the Amur Oblast towns were attributed to the most "environmentally friendly" cluster possible, but on average, the region is indicative of negative GS value. And this is indisputably associated with a fairly large center of coal mining with the region already classified in the cluster no. 3 according to our classification.

\section{Conclusion}

To sum up, this study shows that Russian single-industry towns, being milestones of economic growth not only in the regions, but also in the country as a whole, are under great environmental stress nowadays. And even if, as a whole, the region is characterized by sufficiently high GS values, which indirectly attests to the welfare of the population living in the region, a more detailed analysis proves that the monotowns, which host the enterprises actually providing most of the gross value added of the country, have negative values of GS and are often on the brink of either ecological (if the town-forming enterprise operates successfully) or social catastrophe (if the enterprise is on the threshold of social tension). And since the population in the majority of these cities is relatively small, the problems of this population are form being written in the agenda of regional and national authorities. Yet, it is important to understand that sustainable growth of GS as an indicator of the quality of economic growth, both at regional and national levels, can be achieved only when sustainable growth of each component of the system is ensured. It is necessary to start with the development of differentiated policies for groups of towns that are similar in terms of basic industry and population size. In addition, the author's idea of clustering towns depending on the level of GS can be scaled to absolutely all towns of the Russian Federation and the genuine savings can become if not key ones, but at least some of the tools that could be used to pursue the sustainable development policy for a particular city. 


\section{References}

Barrington-Leigh, C., Escande, A. (2018). Measuring Progress and Well-Being: A Comparative Review of Indicators. In Social Indicators Research, 135, 893-925. DOI: 10.1007/s11205-016-1505-0

Belik, I.S., Pryakhin, D.A. (2013). Sotsial'no-ekologicheskaia sostavliaiushchaia ustoichivogo razvitiia regiona [Socio-ecological component of the region steady development]. In Ekonomika regiona [Regional economics], 3, 142-151. DOI: 10.17059/2013-3-12

Bobylev, S.N., Minakov, V.S., Solovyeva, S.V., Tretyakov, V.V. (2012). Ekologo-ekonomicheskii indeks dlia regionov Rossii [Ecological and economic index of Russian regions. Calculation methodology and indicators]. Moscow, WWF Russia, RIA Novosti.

Bobylev, S.N. (2012). Indikatory ustoichivogo razvitiia dlia Rossii [Sustainable development indicators for Russia]. In Sotsial'no-ekologicheskie tekhnologii [Socio-ecological technologies], 1, 8-18.

Bobylev, S.N., Zubarevich, N.V., Solovyeva, S.V., Vlasov, Yu.S. (2011). Ustoichivoe razvitie: Metodologiia i metody izmereniia: uchebnoe posobie [Sustainable development: Methodology and methods of measurement: training manual]. Moscow, Ekonomika, 2011.

Bolt, K., Matete, M., Clemens, M. (2002). Manual for calculating adjusted net savings. Environmental department, World Bank. Available at: http://documents.worldbank.org/curated/en/436351468320071776/ pdf/406650Savings0manual0200201PUBLIC1.pdf

Brundtland Commission Report of the World Commission on Environment and Development: Our Common Future. UN Documents (1987). Available at: http://www.un-documents.net/wced-ocf.htm

Cobb, C., Halstead, T., Rowe, J. (1995). If the GDP is up, why is America down? In The Atlantic Online, October 1995. Available at: https://www.theatlantic.com/past/docs/politics/ecbig/gdp.htm

Costanza, R., Kubiszewski, I., Giovannini, E., Lovins, H., McGlade, J., Pickett, K.E., Vala, K.R., Roberts, D., De Vogli, R., Wilkinson, R. (2014). Time to Leave GDP behind. In Nature, 505 (7483), 283-85. DOI: $10.1038 / 505283 \mathrm{a}$

Glazyrina, I.P., Zabelina, I.A., Klevakina, E.A. (2010). Uroven' ekonomicheskogo razvitiia i raspredelenie ekologicheskoi nagruzki mezhdu regionami RF [Economic development level and distribution of the ecological load between the Russian regions]. In Journal of New Economic Association, 7, 70-88.

Daly, H.E., Cobb, J.B. (1989). For the Common Good: Redirecting the Economy Toward Community the Environment, and a Sustainable Future. Beacon Press, 482 p.

Korobitsyn, B.A. (2015). Metodicheskii podkhod k uchetu istoshcheniia prirodnykh resursov, izmeneniia sostoianiia okruzhaiushchei sredy $\mathrm{i}$ chelovecheskogo kapitala $\mathrm{v}$ valovom regional'nom produkte [Methodical approach to the account of the natural resources depletion, the environment and human capital change in the gross regional product]. In Ekonomika regiona [Regional economics], 3 (43), 77-88. DOI: 10.17059/2015-3-7

Mekush, G.E. (2011). Kemerovo Region. Sustainable Development: Experience, Problems, Prospects. Moscow, Institute for Sustainable Development of the Public Chamber of the Russian Federation; Center for Environmental Policy of Russia.

Pearce, D.W., Atkinson, G.D. (1993). Capital theory and the measurement of sustainable development: An indicator of "weak" sustainability. In Ecological Economics, 8, 103-108. DOI: 10.1016/09218009(93)90039-9

Pyzhev, A.I., Syrtsova, E.A., Pyzheva, Yu.I., Zander, E.V. (2019). Sovershenstvovanie statistiki ustoichivosti razvitiia rossiiskikh regionov [Improvement of the Russian regions sustainable development statistics]. In Voprosy statistiki [Issues of statistics], 5, 33-42. DOI: 10.34023/2313-6383-2019-26-5-33-42

Pyzheva, Yu.I., Lapo, E.V., Syrtsova, E.A., Pyzhev, A.I. (2020). Sustainability of development of the Russian Far East: assessment based on genuine savings. In Region: ekonomika i sociologiia [Region: Economics and Sociology], 2 (being published).

Ryumina, E.V. (2013). Ekologicheski skorrektirovannyi VVP: sfery ispol'zovaniia i problem otsenki [Ecologically adjusted GDP: spheres of use and estimation problems]. In Ekonomika regiona [Regional economics], 4 (36), 107-115. DOI: 10.17059/2013-4-10 
Syrtsova, E.A., Pyzhev, A.I., Zander, E.V. (2016). Istinnye sberezheniia regionov Sibiri: novye otsenki, starye problemy [Genuine savings of the Siberian regions: new estimates, but old problems]. In ECO, 6, $109-129$.

Zabelina, I.A., Klevakina, E.A. (2011). Otsenka i sravnitel'nyi analiz pokazatelei kachestva ekonomicheskogo rosta $\mathrm{v}$ razreze ekologicheskikh tem [Estimation of the ecological expenses in the produced gross regional product]. In Region: ekonomika i sociologiia [Region: Economics and Sociology], 2, 223-232.

\title{
Устойчивость развития моногородов Сибири и Дальнего Востока: какова цена экономического роста регионов?
}

\section{Ю.И. Пыжева}

Сибирский федеральный университет

Российская Федераџия, Красноярск

\begin{abstract}
Аннотация. Одним из наиболее известных и относительно легко вычисляемых интегральных показателей устойчивости развития является показатель истинных сбережений. В настоящей статье акцент сделан на модификациях методики расчета истинных сбережений для уровня муниципальных образований на примере моногородов Сибири и Дальнего Востока. Такой выбор объекта исследования обусловлен гипотезой о том, что именно муниципалитеты испытывают большую часть экологических и социальных последствий экономического роста регионов. На основе отчетности предприятий сформирована база данных, которая затем использована для расчета истинных сбережений моногородов Сибири и Дальнего Востока. В результате получена новая классификация моногородов, включающая четыре кластера, выделенных в зависимости от уровня истинных сбережений, отрасли специализации и численности населения. Новый подход к классификации моногородов может использоваться региональными и муниципальными органами власти с целью формирования дифференцированной политики устойчивого развития моногородов. Анализ средних истинных сбережений моногородов в разрезе регионов показал, что даже если в целом регион характеризуется достаточно высокими значениями истинных сбережений, то более подробный анализ городов, в которых на самом деле находятся предприятия, обеспечивающие бо́льшую часть валового внутреннего продукта страны, имеют отрицательные значения истинных сбережений и часто находятся на грани экологической или социальной катастрофы.
\end{abstract}

Ключевые слова: устойчивость развития, истинные сбережения, индикаторы устойчивости развития, моногорода, экономика природопользования.

Исследование выполнено при финансовой поддержке РФФИ в рамках научного проекта № 19-010-00841.

Научная специальность: 08.00.05 - экономика и управление народным хозяйством. 